\section{Contents, Volume 15 (2004)}

Adler, P. H. \& Malmqvist, B.: Predation on black flies (Diptera: Simuliidae) by the carnivorous plant Pinguicula vulgaris (Lentibulariaceae) in northern Sweden 124-128

Aslan, I., Calmasur, O. \& Bilgin, O. C.: A morphometric study of Altica oleracea (Linnaeus, 1758) and A. deserticola (Weise, 1889) (Coleoptera: Chrysomelidae: Alticinae)

Aslan, I., Özbek, H. \& Warchalowski, A.: Five new records, new localities and new host plants for the Turkish flea-beetle fauna (Coleoptera: Chrysomelidae: Alticinae).....

138-141

Belokobylskij, S. A. \& Koponen, M.: A new subgenus and species of the genus Pseudobathystomus Belokobylskij (Hymenoptera: Braconidae: Rhyssalinae) from the Canary Islands 225-230

Czechowski, W.: Scarcity of sites suitable for nesting promotes plesiobiosis in ants (Hymenoptera: Formicidae)

211-218

Franzén, M. \& Ranius, T.: Habitat associations and occupancy patterns of burnet moths (Zygaenidae) in seminatural pastures in Sweden. 91-101

Hula, V., Konvicka, M., Pavlicko, A. \& Zdenek, F.: Marsh Fritillary (Euphydryas aurinia) in the Czech Republic: monitoring, metapopulation structure, and conservation of an endangered butterfly... 231-241

Komonen, A., Jonsell, M., Økland, B., Sverdrup-Thygeson, A. \& Thunes, K.: Insect assemblage associated with the polypore Fomitopsis pinicola: a comparison across Fennoscandia. 102-112

Koponen, S., Marusik, Yu.M. \& Potapova, N.K.: Spiders (Araneae) from the Lena and Yana Rivers, Yakutia (Sakha Republic).... 113-118

Kurina, O.: Redescription of Sciophila nitens Winnertz (Diptera: Mycetophilidae) with a new synonymization

193-197

Matveinen-Huju, K.: Habitat affinities of 228 boreal Finnish spiders: a literature review 149-192

Nikitsky, N. B. \& Schigel, D. S.: Beetles in polypores of the Moscow region, Russia: checklist and ecological notes 6-22

Nittérus, K., Gunnarsson, B. \& Axelsson, E.: Insects reared from logging residue on clear-cuts .....................53-61

Polevoi, A. \& Hedmark, K.: New species of the genus Boletina Winnertz (Diptera: Mycetophilidae) from Fennoscandia ..... 23-33

Satar, A. \& Özbay, C.: Remarks on Neuroptera of Southeastern Turkey 219-224

Starý, J. \& Salmela, J.: Redescription and biology of Limonia badia (Walker) (Diptera: Limoniidae)

$41-47$

Thunes, K. H., Skartveit, J., Gjerde, I., Starý, J., Solhøy, T., Fjellberg, A., Kobro, S., Nakahara, S., zur Strassen, R.,
Vierbergen, G., Szadziewski, R., Hagan, D. V., Grogan Jr., W. L., Jonassen, T., Aakra, K., Anonby, J., Greve, L., Aukema, B., Heller, K., Michelsen, V., Haenni, J.P., Emeljanov, A. F., Douwes, P., Berggren, K., Franzen, J., Disney, R. H. L., Prescher, S., Johanson, K. A., Mamaev, B., Podenas, S., Andersen, S., Gaimari, S. D., Nartshuk, E., Søli, G. E. E., Papp, L., Midtgaard, F., Andersen, A., von Tschirnhaus, M., Bächli, G., Olsen, K. M., Olsvik, H., Földvári, M., Raastad, J. E., Hansen, L. O. \& Djursvoll, P.: The arthropod community of Scots pine (Pinus sylvestris L.) canopies in Norway ..... 65-90

Tóth, P., Èerný, M. \& Cagáò, L.: First records of Melanagromyza cuscutae Hering, 1958 (Diptera: Agromyzidae) from Slovakia and its new host plant.........48-52

Voolma, K., Mandelshtam, M. J., Shcherbakov, A. N., Yakovlev, E. B., Õunap, H., Süda, I., Popovichev, B. G., Sharapa, T. V., Galasjeva, T. V., Khairetdinov, R. R., Lipatkin, V. A. \& Mozolevskaya, E. G.: Distribution and spread of bark beetles (Coleoptera: Scolytidae) around the Gulf of Finland: a comparative study with notes on rare species of Estonia, Finland and NorthWestern Russia ..... 198-210

Vujić, A., Radenković, S., Nielsen, T. R. \& Šimić, S.: A new European species of genus Eristalis Latreille, 1804 (Diptera: Syrphidae) 119-123

Yang, M., Pyörnilä, A. \& Meyer-Rochow, V. B.: UV-reflectivity of parafocal eyespot elements on butterfly wings in normal and abnormal specimens ....................34-40

Yao, Y. \& Yang, Z.: A new species of Ormyridae (Hymenoptera: Chalcidoidea) parasitizing a gall-making weevil on twigs of the bunge hackberry tree in China 142-148

Yu, X.-D., Luo, T.-H. \& Zhou, H.-Z.: Carabus (Coleoptera: Carabidae) assemblages of native forests and non-native plantations in Northern China. 129-137

\section{Book reviews}

Koivula, M. 2004: Walking in Lindroth's footsteps - the life history of North American ground beetles (Larochelle, A. \& Lariviére, M.-C. 2003: A Natural history of the Gound-Beetles (Coleoptera: Carabidae) of America north of Mexico) ................................. 63-64

Schmidt, S. 2004: Electronic tool for Noctuidae identification (Rötschke, H. \& Huber, K. 2003: Noctuid moths of Central Europe - an interactive identification tool on CD-ROM.). $62-63$

\section{Other}

Index to genera and species, Volume 15 (2004) .....242-255 Contents, Volume 15 (2004)...................................... 256 